\title{
Four-dimensional model of Cretaceous depositional geometry and sediment flux in the northern Great Valley forearc, California
}

\section{Authors: Devon A. Orme and Stephan A. Graham}

This is a postprint of an book chapter that originally appeared in GSA Special Papers. The final version can be found at https://dx.doi.org/10.1130/2018.2540(18).

Orme, Devon A., and Stephan A. Graham. "Four-dimensional model of Cretaceous depositional geometry and sediment flux in the northern Great Valley forearc, California." GSA Special Papers 540. DOI: 10.1130/2018.2540(18).

Made available through Montana State University's ScholarWorks 


\title{
Four-dimensional model of Cretaceous depositional geometry and sediment fluxinthenorthernGreatV alley forearc, California
}

\author{
Devon A. Orme \\ Department of Earth Sciences, Montana State University, Bozeman, Montana 59717, USA, and \\ Department of Geological Sciences, Stanford University, Stanford, California 94305, USA \\ Stephan A. Graham \\ Department of Geological Sciences, Stanford University, Stanford, California 94305, USA
}

\begin{abstract}
The Great Valley forearc basin records Jurassic(?)-Eocene sedimentation along the western margin of North America during eastward subduction of the Farallon plate and development of the Sierra Nevada magmatic arc. The four-dimensional (4-D) basin model of the northern Great Valley forearc presented here was designed to reconstruct its depositional history from Tithonian through Maastrichtian time. Based on >1200 boreholes, the tops of 13 formations produce isopach maps and cross sections that highlight the spatial and temporal variability of sediment accumulation along and across the basin. The model shows the southward migration of depocenters within the basin during the Cretaceous and eastward lapping of basin strata onto Sierra Nevada basement. In addition, the model presents the first basement map of the entire Sacramento subbasin, highlighting its topography at the onset of deposition of the Great Valley Group. Minimum volume estimates for sedimentary basin fill reveal variable periods of flux, with peak sedimentation corresponding to deposition of the Sites Sandstone during Turonian to Coniacian time. Comparison of these results with flux estimates from magmatic source regions shows a slight lag in the timing of peak sedimentation, likely reflecting the residence time from pluton emplacement to erosion. This model provides the foundation for the first three-dimensional subsidence analysis on an ancient forearc basin, which will yield insight into the mechanisms driving development of accommodation along convergent margins.
\end{abstract}

\section{INTRODUCTION}

Forearc basins record the erosional history of convergent margins during subduction. Developing between a magmatic arc and oceanic trench, strata deposited within a forearc basin provide information on the tectonic evolution of the upper plate in response to changes in subduction (e.g., convergence rate or sub- duction angle) and evolution of the arc. Many modern forearcs are erosive and contain thin $(<3 \mathrm{~km})$ sedimentary successions (Clift and Vannucchi, 2004). In contrast, forearc basins that develop along accretionary margins, landward of an accretionary wedge, may develop thick $(>6 \mathrm{~km})$ sedimentary sequences recording the evolution of a margin over tens of millions of years. Many ancient forearc basins were destroyed by erosion or were 
highly deformed as they were incorporated into fold-and-thrust belts of collisional orogens (e.g., Midland Valley basin, Indus basin, Xigaze forearc; Ingersoll, 2012). However, if subduction is supplanted by a transform system (e.g., Tamworth Trough, Hokonui basin), a forearc basin may be preserved with relatively little deformation and thus provide an opportunity to study the evolution of that ancient convergent margin.

The Great Valley forearc basin of California is one of the best-studied ancient forearc basins, with over $100 \mathrm{yr}$ of scientific and petroleum exploration (Fig. 1). The forearc developed along the west coast of North America as part of a series of forearc basins that evolved during eastward subduction of the Farallon plate between the Jurassic and Paleogene (Dickinson and Seely, 1979). Sedimentary strata within the Great Valley are $>13 \mathrm{~km}$ thick and preserve a >100 m.y. record of convergent-margin processes. The basin is divided into two subbasins separated by the Cenozoic Stockton arch, namely, the Sacramento Basin in the north and the San Joaquin Basin in the south (Fig. 1). In the Sacramento basin, extensive work to understand the biostratigraphy, depositional history, and provenance of the Great Valley has contributed greatly to understanding these tectonic settings (e.g., Goudkoff, 1945; Hackel, 1966; Morrison et al., 1971; Ingersoll, 1978; Dickinson and Seely, 1979; Graham,

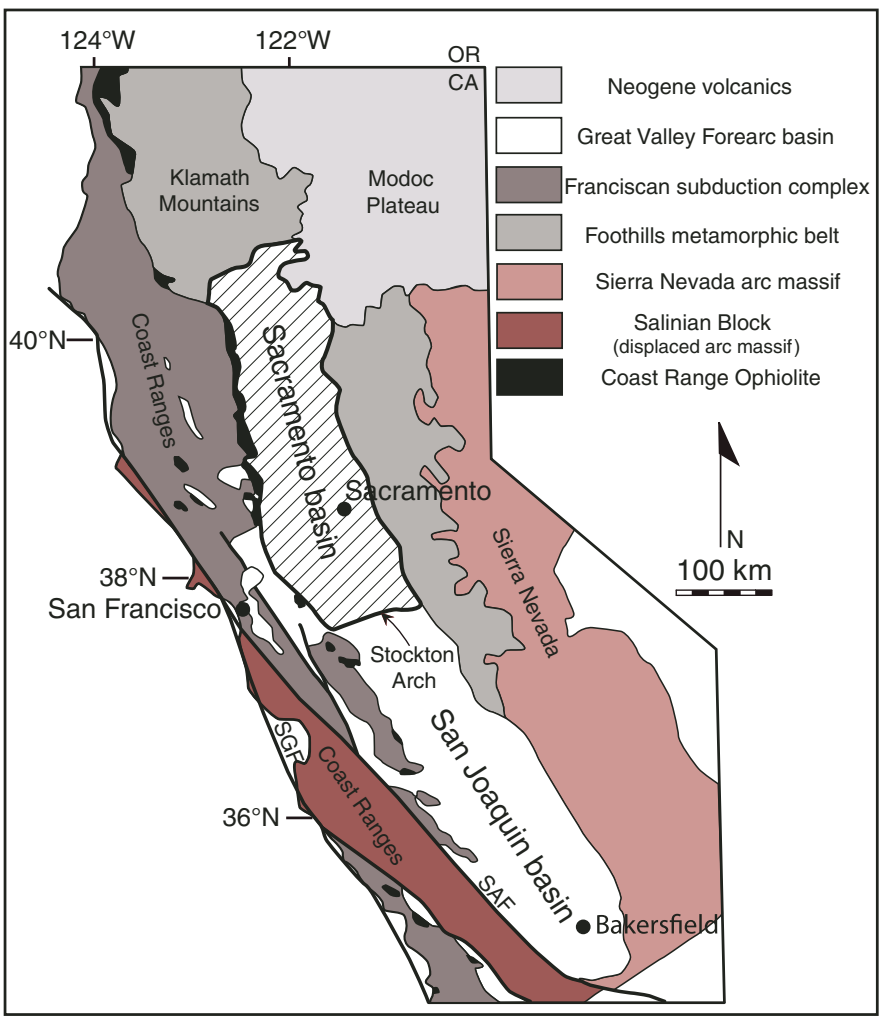

Figure 1. Generalized geologic map of California, after Williams and Graham (2013) and Dickinson (1995). Sacramento Basin study area is outlined by bold black line. SAF-San Andreas fault; SGF-San Gregorio fault; OR-Oregon; CA-California.
1981; Almgren and Hacker, 1984; Moxon, 1988; Williams, 1997). Much of our knowledge of this basin derives from application of sedimentary facies analysis, sandstone petrography, and detrital-zircon geochronology to the western margin of the basin, where Jurassic(?)-Campanian forearc strata are exposed as an eastward-dipping homoclinal belt. Resulting interpretations (e.g., Ingersoll, 1979; Moxon, 1988; DeGraaff-Surpless et al., 2002; Surpless et al., 2006; Sharman et al., 2014) led to the recognition that many forearc basins preserve upward-shoaling sequences from deep-marine turbidite-fan to fluvial-deltaic deposits derived from unroofing of neighboring magmatic-arc systems (e.g., Dickinson and Rich, 1972; Dickinson and Seely, 1979; Dickinson, 1995).

Unlike many forearc basins, the Great Valley is petroleum bearing, and since the late 1800s, subsurface exploration has led to extensive oil and gas production (Graham, 1987). Most seismic-reflection surveys of the Great Valley are proprietary, but limited published seismic-reflection lines have yielded great insight into the stratigraphic architecture of the basin fill, including its relationship with underlying basement and wedge-type geometry (e.g., Constenius et al., 2000; Mitchell et al., 2010; Williams and Graham, 2013). In addition, production of oil from the southern part of the Great Valley basin has resulted in numerous petroleum-systems models (e.g., Scheirer, 2013). In contrast, the primarily gas-producing northern part of the forearc lacks a complete basin model that incorporates the entire Mesozoic stratigraphy, notwithstanding the compilation work of Scheirer et al. (2007).

In this study, we used data from $>1200$ boreholes to construct the first four-dimensional (4-D) basin model of the northern Great Valley forearc. The study focuses on the northern part of the forearc, the Sacramento Basin, an area of $\sim 25,000 \mathrm{~km}^{2}$, bounded on its northern and southern boundaries by the Klamath Mountains and Stockton arch, respectively (Fig. 1). The purpose of the model is to (1) reconstruct the primary depositional-basin architecture, (2) produce structural-contour and isopach maps for the entire Cretaceous basin fill, and (3) perform a quantitative minimum-volume analysis of basin fill. Ultimately, this model is an effort to provide the foundations upon which to develop more detailed petroleum-system models for the Sacramento Basin and to investigate the mechanisms that drove the development of accommodation in one of the world's thickest forearc-basin sediment accumulations. This work builds upon the contributions of William R. Dickinson, a pioneer of California geology and forearc basins. Through development of sandstone petrographic methods, which sought to explain the tectonic settings of sedimentary basins, and extensive field work on the western outcrop belt, Dickinson and his students were the first to define the evolution of the Great Valley forearc in the context of plate tectonics (e.g., Dickinson, 1970, 1995; Dickinson and Rich, 1972; Dickinson and Seely, 1979; Dickinson et al., 1979, 1987). In this paper, we build upon Dickinson's legacy and seek to honor him by continuing his quest to understand the relationships between forearc basins and their magmatic source regions. 


\section{GEOLOGIC SETTING}

The Jurassic(?)-Eocene Great Valley forearc developed as an elongate trough between the Franciscan subduction complex to the west and Sierra Nevada magmatic arc to the east (Dickinson and Rich, 1972; Dickinson, 1995). The Franciscan complex, comprising diverse petrotectonic elements, including mélange containing blueschist-facies tectonic blocks, accreted westward, beginning ca. $150 \mathrm{Ma}$ (Ernst, 1970; Dumitru et al., 2010; Wakabayashi, 2015). A period of high-flux magmatism between 125 and $85 \mathrm{Ma}$ characterized the Sierra Nevada arc before magmatism and deformation stepped into the continental interior during a period of flat-slab subduction (Dickinson and Snyder, 1978; Ducea, 2001; DeCelles, 2004; DeCelles and Graham, 2015). The forearc primarily developed atop Jurassic ophiolitic basement, termed the Coast Range (or Great Valley) ophiolite, in the central and western parts of the basin; Paleozoic-Mesozoic Sierra Nevada metamorphic and igneous rocks in the east; and accreted Triassic-Jurassic intraoceanic island arc terranes in the Klamath Mountains to the north (Fig. 1).

The northeast-trending Stockton arch subdivides the Great Valley forearc into the Sacramento and San Joaquin Basins (Fig. 1). This study focuses on the Sacramento Basin, which preserves a longer record of forearc sedimentation from the latest Jurassic(?) to Quaternary (<13 km thick; Fig. 2; Ingersoll, 1976; Moxon, 1990; Williams and Graham, 2013). Jurassic(?)-Lower Cretaceous (Berriasian-Albian) strata are exposed along the homoclinal western outcrop belt, and in the subsurface, in the northwest part of the current basin area. Importantly, the western outcrop belt represents strata deposited in the middle of the basin, as structural deformation and uplift shortened the width of the basin in the Cenozoic (Ingersoll, 1976, 1979; Dickinson and Seely, 1979); remnants of strata originally deposited along the western flank are found structurally atop the Franciscan complex in parts of the Coast Ranges. The Sacramento Basin currently averages $72 \mathrm{~km}$ in width and $323 \mathrm{~km}$ in length, approximately two thirds the likely width of the basin in the Late Cretaceous, based on comparisons with modern continental forearc basins (Williams and Graham, 2013).

We summarize Cretaceous stratigraphy in Figure 2, following age assignments of Williams and Graham (2013) and Almgren (1984), which were based on benthic zones from Almgren (1986) and Berry (1974). The age of the basement varies across the basin, but the top of the Coast Range ophiolite is Kimmeridgian (Ingersoll, 1982; Shervais et al., 2005), between ca. $153 \mathrm{Ma}$ and ca. $150 \mathrm{Ma}$, following the Geological Society of America 2012 Time Scale (Walker et al., 2012). The basal units deposited unconformably atop basement are the Stony Creek and Lodoga Formations (Fig. 2). These strata record the transition from Tithonian(?)-Berriasian volcaniclastic, ophiolitic, and pelagic sediments directly atop the ophiolite to Valanginian-Albian mudstone and conglomerate (Fig. 2; Ingersoll, 1976, 1982). Locally, there is a discontinuity between the two formations, which most researchers interpret to be a product of syndepositional faulting and a hiatus in forearc sedimentation (Constenius et al., 2000). The precise age of the basal Stony Creek Formation is uncertain, as fossil assemblages are interpreted as Tithonian (e.g., Jones et al., 1969), but more recent work documented the presence of Berriasian-Hauterivian detrital zircon, suggesting a Cretaceous

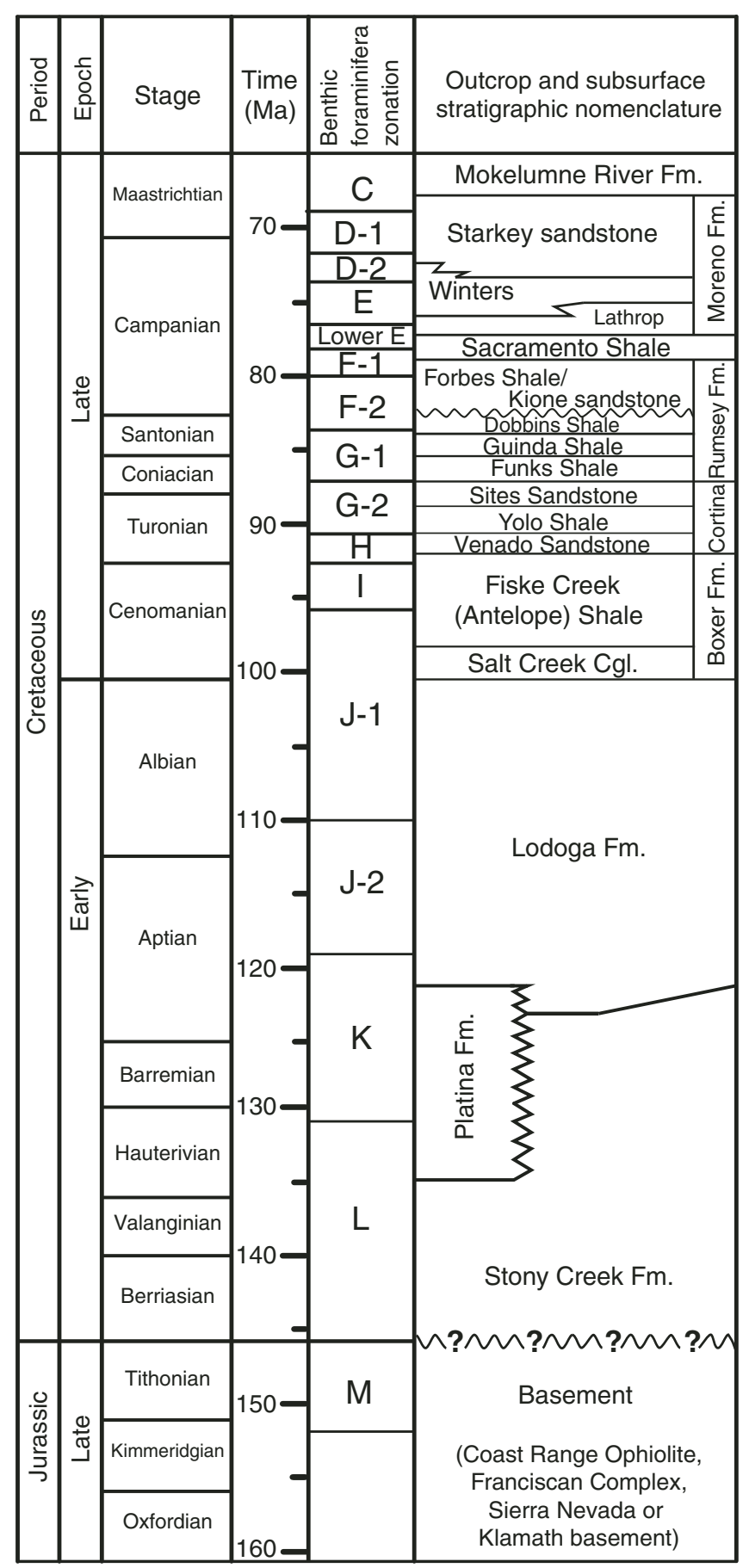

Figure 2. Upper Jurassic(?) to Maastrichtian stratigraphy of the Sacramento Basin, after Williams and Graham (2013), DeGraaffSurpless et al. (2002), and Almgren (1984). Fm-Formation; $\mathrm{Cgl}-$ Conglomerate. 
age (Surpless et al., 2006). Therefore, we applied a "?" to the age to highlight this age uncertainty. The Aptian-Albian Lodoga Formation underlies the Cenomanian Boxer Formation.

The Cenomanian to earliest Campanian was a period of rapid sedimentation, with deposition of the Venado, Yolo, Sites, Funks, Guinda, and Dobbins units (Fig. 2; Moxon, 1990). The central part of the basin, now exposed along the west-side outcrops, records a north-to-south sequence of Cenomanian slope and slope-channel deposits, Turonian-Coniacian inner-fan facies, Santonian midfan facies, and Lower Campanian basinplain deposits (Ingersoll, 1976; Moxon, 1990; Nilsen, 1990). This sequence is consistent with the subsurface observations of eastward onlapping and transgressive sequences preserved along the east side of the basin (Haggart and Ward, 1984; Williams, 1997; Williams and Graham, 2013). Southward, bathymetric deepening of the basin is also evidenced by the north-to-south transition from slope mudstone to midfan channel to distal deep-marine turbidite fan lobe facies of the Venado Sandstone (Ingersoll, 1976). By the middle Santonian, Williams submarine canyon had incised at least $1.5 \mathrm{~km}$ into forearc strata and subsequently been filled with the Upper Santonian-Lower Campanian Dobbins and Forbes Shales (Williams, 1997; Williams et al., 1998). Recognition of this paleocanyon is important for stratigraphic correlation and understanding the role of tectonics as the primary control versus eustasy on the basin's history.

Middle to late Campanian southward delta progradation yielded the neritic Kione deltaic succession, the Forbes deltaslope and basin-floor facies, and bathyal Sacramento Shale (Fig. 2), likely fed by rivers draining the Sevier retroarc hinterland in Idaho (Dumitru et al., 2015). By the late Campanian, the northern Sacramento Basin filled and served as a zone of sediment bypass. The southern Sacramento Basin began filling in the latest Maastrichtian during deposition of the Starkey Sandstone and Mokelumne River Formation. The filling of the Sacramento Basin was coeval with an increase in plate convergence rates (120-150 km/m.y.) and initiation of flat-slab subduction between 80 and $74 \mathrm{Ma}$, and the Laramide orogeny of the retroforeland (Dickinson and Snyder, 1978; DeCelles and Graham, 2015).

A change in the geometry of basin deposition driven by localized faulting and submarine-canyon incision occurred in the Paleogene. In the southern part of the basin, fault-bounded depocenters evolved during periods of active slip (e.g., Midland and Kirby Hills faults). By the mid-Paleocene, the down-to-the-north Stockton fault had developed, separating the Great Valley into the Sacramento and San Joaquin subbasins (Almgren, 1984). Interplay of tectonics and eustatic sea-level changes characterized the Sacramento Basin during this period, as evidenced by development of submarine canyons and cycles of deposition of bathyal shale and sandstone versus estuarine and fluvial sandstone (Almgren, 1984; Dickinson et al., 1979). Much of the Oligocene and Miocene record was lost to a basin-wide unconformity, which coincides with the change from convergent to transform motion along the plate boundary (e.g., Dickinson et al., 1979; Graham et al., 1989).
The Sacramento Basin is primarily a gas-producing region, with minor oil-producing fields. The major gas systems are the Dobbins-Forbes and the Winters-Domengine (Scheirer et al., 2007). The source rocks for these systems are primarily shale in the Dobbins, Forbes, Sacramento, and Winters units (Graham, 1987). The burial-history analysis of Zieglar and Spotts (1978) suggests gas generation likely occurred from the Late Cretaceous (ca. 80-70 Ma) to the late Miocene (ca. $10 \mathrm{Ma}$ ). A complete summary of the role of gas generation and migration in the Sacramento Basin is beyond the scope of this study, but our 4-D basin model provides the foundation for future petroleumsystem modeling.

\section{METHODS}

\section{Database Construction}

This study primarily used boreholes from the California Division of Oil, Gas, and Geothermal Resources (DOGGR) database to reconstruct basin geometry and stratigraphic thicknesses of the Sacramento Basin. The database consists of 1205 boreholes, from which we chose 13 horizons corresponding to the tops of formations. The 13 horizons included the top of the underlying basement ( $n=148$ boreholes) and 12 formations deposited from the Late Jurassic(?)-Aptian through Maastrichtian (Figs. 2 and 3). The formations, with the number of boreholes used to construct each surface, included the following: (1) Stony Creek Formation $(n=9),(2)$ Lodoga Formation $(n=10)$, (3) Venado Formation $(n=21)$, (4) Yolo Formation $(n=17)$, (5) Sites Sandstone $(n=21)$, (6) Guinda Shale $(n=112)$, (7) Dobbins Shale $(n=$ 257), (8) Forbes Shale ( $n=356)$, (9) Sacramento Shale $(n=260)$, (10) Winters Formation ( $n=194)$, (11) Starkey Sandstone $(n=287)$, and (12) Mokelumne River Formation $(n=129)$. The smaller number of data points for older strata reflects limited deep borehole penetration.

With the aid of 36 previously interpreted boreholes from Williams (1997), we identified the formation tops within individual boreholes based on our interpretation of sandstone versus shale, inferred from sharp changes in spontaneous potential (SP) and resistivity. For example, formations dominated by sandstone, such as the Starkey Sandstone or Sites Sandstone, show an abrupt increase in SP and resistivity compared with shale. No borehole penetrated all 13 horizons; the resistivity log from Mobil Glide-Court \#65-10, which was first drilled and sampled in 1955 and again in 2005, is reproduced in Data Repository Supplementary Material I as an example. ${ }^{1}$ In some cases, identification of every formation within a drill core was not possible, either due to poor quality of borehole logs or lack of a clear

${ }^{1}$ GSA Data Repository Item 2018262, Supplementary Materials I-IV: Example of borehole resistivity log, isopach maps, data tables of all borehole locations, and depth picks for all 13 stratigraphic horizons, is available at www.geosociety .org/datarepository/2018/, or on request from editing@geosociety.org or Documents Secretary, GSA, P.O. Box 9140, Boulder, CO 80301-9140, USA. 
change in the SP or resistivity patterns. The database contains the depths to the top of each formation from borehole records where formation top identification was possible (Supplementary Material IV [see footnote 1]). The elevation of the kelly bushing (KB) was used as a datum to determine the true vertical depth (TVD) below sea level to the top of each formation. All spatial positions used North American Datum 1927, as $>90 \%$ of borehole records are in this reference frame.

Borehole penetration of the Jurassic igneous and metamorphic basement is limited in the Sacramento Basin, but we used 147 boreholes to reconstruct its geometry. We incorporated the picks from 29 basement-penetrating boreholes compiled by Brabb (2011). In addition, we compared our picks with an east-west-trending seismic-reflection line (Line 3, AYD-3) and corresponding velocity survey from Constenius et al. (2000) to confirm the depth to the top of basement, top of the Stony Creek Formation, and the Cretaceous-Paleocene unconformity in the northernmost Sacramento Basin. Unfortunately, threedimensional (3-D) seismic-reflection surveys from this part of the basin are proprietary and thus were not available for incorporation into the model.

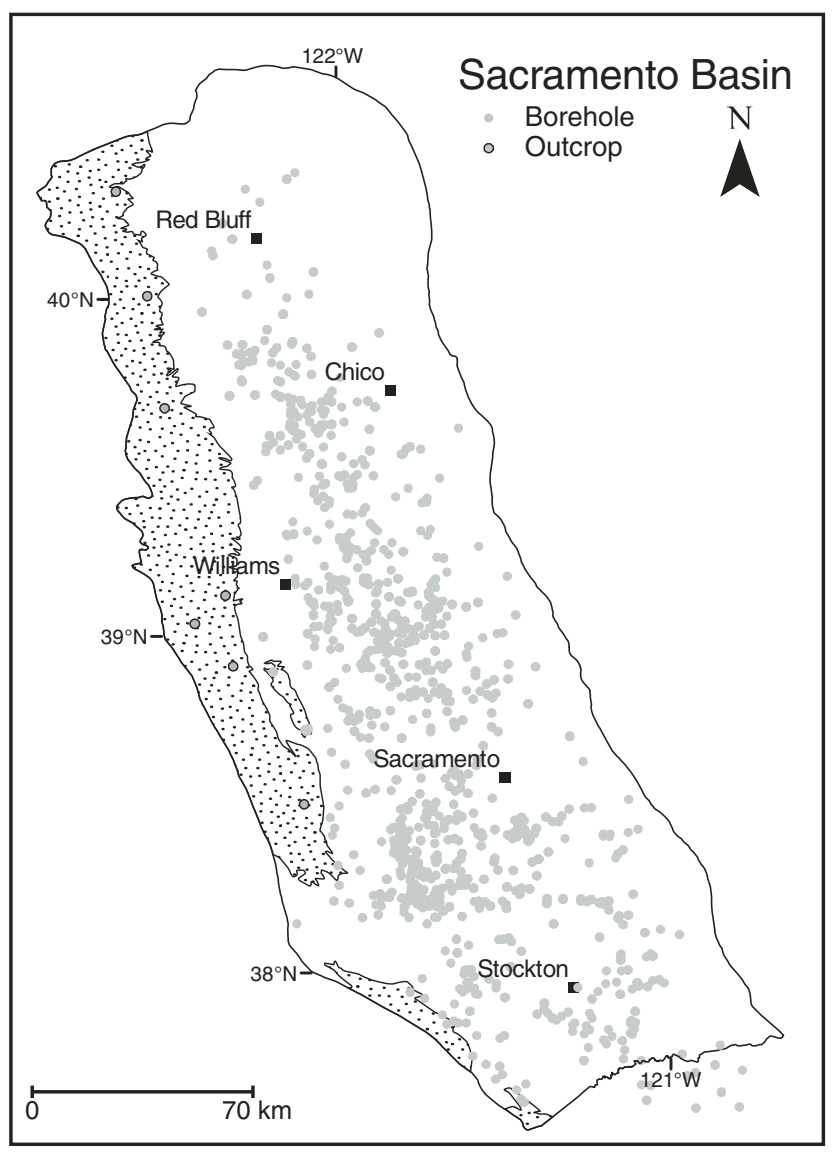

Figure 3. Outline of Sacramento Basin with locations of boreholes $(n=1205)$ and outcrop sections $(n=7)$. Location of outcrop stratigraphy is outlined by stippled pattern.
In the Great Valley forearc, stratigraphic interpretation must address the structural overprint of Cenozoic deformation (e.g., Constenius et al., 2000; Williams and Graham, 2013). This primarily affects the west side of the basin, which is exposed within an east-dipping homocline. We subscribe to the widely held view that the homocline represents a continuum of late Mesozoic sedimentation, but we recognize that Unruh et al. (1995) placed several west-vergent back thrusts within the homocline. Even if correct, their cross sections suggest little duplication or omission of strata resulting in distortions of original thickness, at least for Upper Cretaceous strata. Moxon (1988) and Williams (1997) reconstructed paleo-water depths during deposition and stratigraphic thicknesses of the western margin of the basin by flattening the Sacramento Shale, which is interpreted as having near-original horizontality, as a reference for primary architecture. In this study, we incorporated the paleodepth values from seven outcrop localities studied by Moxon (1988) and Williams (1997) as "pseudo-boreholes" within the basin model (Fig. 3).

\section{Model Construction}

Following the selection of formation tops from resistivity logs, we imported the data set into $\operatorname{ArcMap}^{\mathrm{TM}} 10.5$ (ESRI, 2016) for initial quality control. This allowed visualization of the depth to the top of each formation, as well as comparison of the individual borehole picks for a specific unit with neighboring boreholes and with formations above and below each pick. Visualization of the data highlighted the need for "pseudo-picks" in the southern part of the basin, as most boreholes did not penetrate deeper than the top of the Campanian Sacramento Shale. As a result, deeper horizons (i.e., Guinda, Dobbins and Forbes) lacked the data necessary to construct a surface below that of the younger horizons (i.e., Sacramento Shale, Winters Shale, Starkey Sandstone, and Mokelumne River Formation). Therefore, 16 boreholes that only penetrated to the Sacramento Shale were chosen and assigned pseudo-tops for the formations deposited atop basement, but prior to deposition of the Sacramento Shale, namely, the Guinda, Dobbins, and Forbes formations (Supplementary Material IV [see footnote 1]). The depth to the top of these pseudo-picks was based on the nearest penetrating borehole, and the thickness between formations was maintained. As the boreholes in the DOGGR database are in feet, all depths were converted to meters within $\operatorname{ArcMap}^{\mathrm{TM}}$.

Structural surfaces of each formation were constructed in Move $^{\mathrm{TM}}$ (granted by Midland Valley's Academic Software Initiative). Surfaces for each formation were generated using the inverse distance weighted (IDW) interpolation method, which determines cell values using a linearly weighted combination of a set of sample points, whereby the weight is a function of the inverse distance (Shepard, 1968). This method was chosen over other interpolation methods such as Delaunay triangulation because the density of borehole picks for each formation varied across the area. The basement surface was generated first and extended to the edges of the Sacramento Basin outline (Fig. 4). 

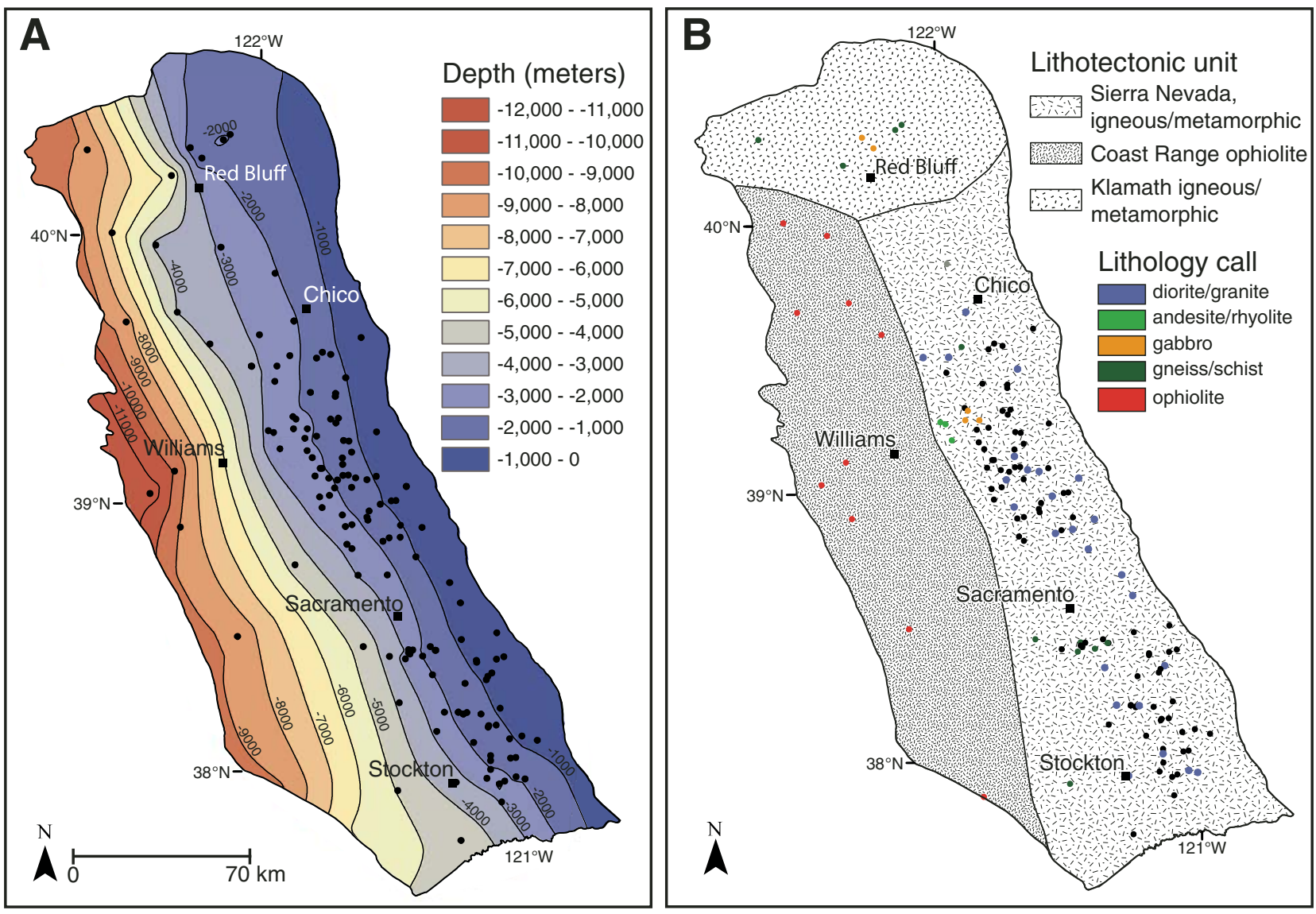

Figure 4. (A) Depth to top of basement constructed from 147 boreholes and seven outcrop localities. Basement reaches maximum depth of $\sim 11,582 \mathrm{~m}$ west of Williams. (B) General lithologic map of basement underlying Sacramento Basin, based on borehole records from on-site geologists. Basement is divided into three lithologic units: Sierra Nevada igneous and metamorphic rocks in the east, Coast Range ophiolite in the west, and igneous and metamorphic rocks of the Klamath Mountains to the north.

The surfaces for each of the 12 sedimentary formations were extended to the basin outline and split by the basement surface (Fig. 5). The shallowest four formations (Sacramento, Winters, Starkey, and Mokelumne) occupy the southern half of the basin and were not extended beyond the areal extent of their data (Fig. 5). In some cases, the contrast in the density of borehole picks between formations required manual adjustment of the surfaces. For example, the high number of boreholes that penetrated the Guinda Shale $(n=112)$ in the southern part of the basin resulted in the Guinda surface projecting below the Sites Sandstone surface. In cases such as this, the underlying surface was adjusted by using the nearest borehole picks as a guide and maintaining thicknesses. All surfaces are shown with locations of their respective borehole picks to highlight where the density of data affected the surface interpolations (Fig. 5).

To study spatio-temporal changes in sediment thickness (e.g., Scheck and Bayer, 1999; Posamentier et al., 2007), isopach maps for each formation were constructed by subtracting the depth of a surface from its underlying surface in order to calculate its thickness over its areal extent (Table 1; Supplementary
Material II [see footnote 1]). In many cases, the "top" surface had multiple underlying surfaces, such as the Lodoga Formation, which was deposited atop the Stony Creek Formation and basement. To account for this, the surface geometry function in Move ${ }^{\mathrm{TM}}$ accepts multiple inputs for the target "bottom" surface and calculates a thickness between the surface of interest and its underlying units. The volume of each formation was calculated using the tetravolume function in Move ${ }^{\mathrm{TM}}$ (Fig. 6; Table 1). This function uses tops and bottoms of surfaces as inputs and divides intervening areas into tetrahedra (cell size $=500 \mathrm{~m}$ ) that take into account changes in area with depth. Although these volumes are minimum estimates, as they are derived from compacted thicknesses, they are useful for comparative purposes, and future work will use this model as the foundation for decompacting strata in the Sacramento Basin. Biostratigraphic data from Moxon (1988) and Williams (1997) were used to assign horizon ages and allow for temporal comparison of stratal volumes (Table 1). In addition, cross sections were generated to capture basin architecture. Two north-south and four east-west sections were constructed (Fig. 7). Due to variability in stratigraphic thickness, east-west 

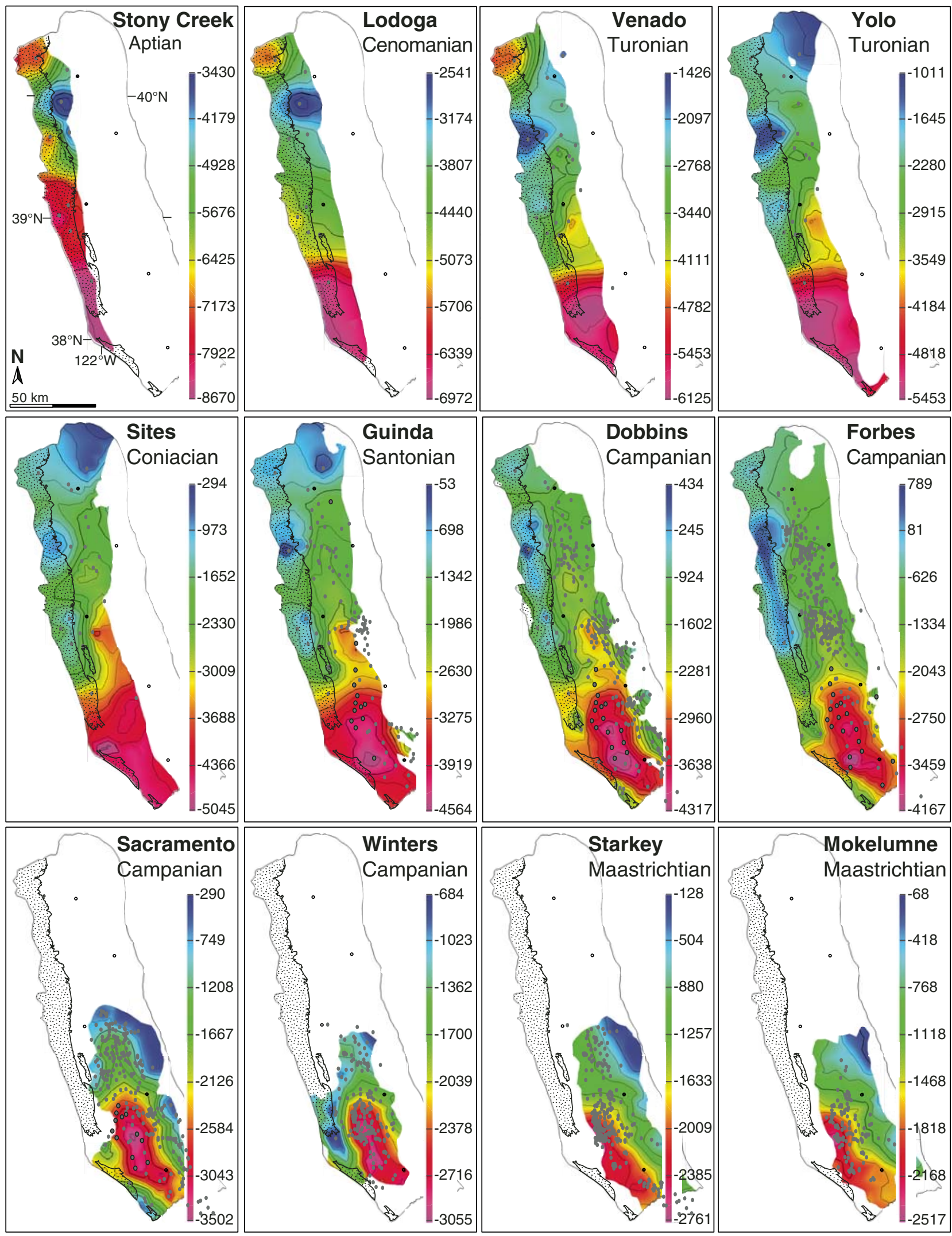

Figure 5. Structural contour maps showing depth to top of 12 stratigraphic surfaces used in this study. Each formation is shown at a different scale (in meters) due to variability of depths between surfaces. Maps show overall southward deepening of basin. White regions represent areas where specific formations were not deposited or were subsequently eroded. Locations of boreholes used to construct each surface are shown by gray ovals, with pseudo-surface picks highlighted with black borders (see text for explanation). Refer to Figure 3 for names of towns shown by black circles. 
TABLE 1. FORMATION TOPS, SACRAMENTO BASIN

\begin{tabular}{|c|c|c|c|c|c|}
\hline Formation name & $\begin{array}{l}\text { Surface age } \\
(\mathrm{Ma})\end{array}$ & $\begin{array}{c}\text { Mean thickness } \\
(\mathrm{m})\end{array}$ & $\begin{array}{c}\text { Volume } \\
\left(\mathrm{km}^{3}\right)\end{array}$ & $\begin{array}{c}\text { Sediment accumulation rate } \\
\left(\mathrm{km}^{3} / \mathrm{m} . \mathrm{y} .\right)\end{array}$ & Number of borehole picks \\
\hline Mokelumne River & 65.0 & 170 & 3267 & 1307 & 129 \\
\hline Starkey & 67.5 & 223 & 6308 & 1147 & 287 \\
\hline Winters & 73.0 & 188 & 4009 & 1002 & 194 \\
\hline Sacramento/Kione & 77.0 & 332 & 6566 & 4377 & 260 \\
\hline Forbes & 78.5 & 252 & 20,639 & 5160 & 356 \\
\hline Dobbins & 82.5 & 254 & 13,455 & 8970 & 257 \\
\hline Guinda/Funks & 84.0 & 258 & 14,119 & 5883 & 112 \\
\hline Sites & 86.4 & 411 & 17,453 & 15,866 & 21 \\
\hline Yolo & 87.5 & 426 & 15,894 & 4541 & 17 \\
\hline Venado/Fiske Creek & 91.0 & 709 & 23,434 & 2343 & 21 \\
\hline Lodoga & 101.0 & 1028 & 30,057 & 1503 & 10 \\
\hline Stony Creek & 121.0 & 998 & 17,208 & 717 & 9 \\
\hline Basement & 153.0 & N/A & N/A & N/A & 147 \\
\hline
\end{tabular}

and north-south cross sections are shown at $2 \times$ and $10 \times$ vertical exaggeration, respectively.

\section{Model Limitations}

Our 4-D basin model cannot capture every geologic or geometric detail of Sacramento Basin stratigraphy due to the range of spatial and temporal scales. First, the spatial distribution of borehole picks from Aptian-Coniacian stratigraphy is highly variable. For example, the Sites Sandstone has very few penetrating boreholes in the north and at the latitude of Sacramento (Fig. 5). In contrast, units deposited during the Santonian and Maastrichtian have a more even distribution of borehole picks that cover their interpolated area well (Fig. 5). Thus, regions of surfaces from the older stratigraphic units that lack borehole picks are heavily dependent on the IDW interpolation method.

Second, division of strata into discrete formations resulted in several formations not being included as separate surfaces where it was problematic to identify them within borehole records or where they are very thin $(<100 \mathrm{~m})$. Specifically, very few boreholes penetrated the Fiske Creek Shale or Salt Creek Conglomerate (Fig. 2) because of their limited extent or thickness, respectively. Therefore, the stratigraphy represented by the top of the Venado Sandstone may include rocks deposited as part of Salt Creek and Fiske Creek stratigraphy; these ambiguities are minor compared to the scale of the model. In addition, incorporation of the Kione deltaic system (i.e., Kione sandstone; Fig. 2) proved challenging due its limited spatial extent and lack of preservation due to incision by the Cenozoic Princeton submarine canyon (Dickinson et al., 1979; Almgren and Hacker, 1984). The Kione system is time-transgressive through the Campanian and overlies the Forbes Shale in the north but interfingers with basinal and submarine-fan sandstone of the Forbes Shale to the west and south (Graham, 1981). Inclusion of the Kione delta stratigraphy is important for future refinement of our model, but these details are beneath the scale of this study. Exclusion of these stratigraphic units results in some formations spanning greater depositional time than implied by their names. For example, the time interval between deposition of the Sites Sandstone and the top of the Guinda Shale (86.4-84.0 Ma) does not include a separate surface for the top of the Funks Shale, as its shale is difficult to distinguish from Guinda Shale (Fig. 2). Thus, the volume of rock accumulated during this time interval is accurate, but the surface name (i.e., Guinda) does not reflect the inclusion of Funks stratigraphy (Table 1). In the future, this database will provide the foundation for petroleum-systems modeling of smaller regions of the basin, as the density of boreholes in certain areas allows for correlation of individual lithofacies, but incorporation of gas plays such as the Kione-Forbes or resolving individual sandstone bodies within formations are beyond the scope of this study.

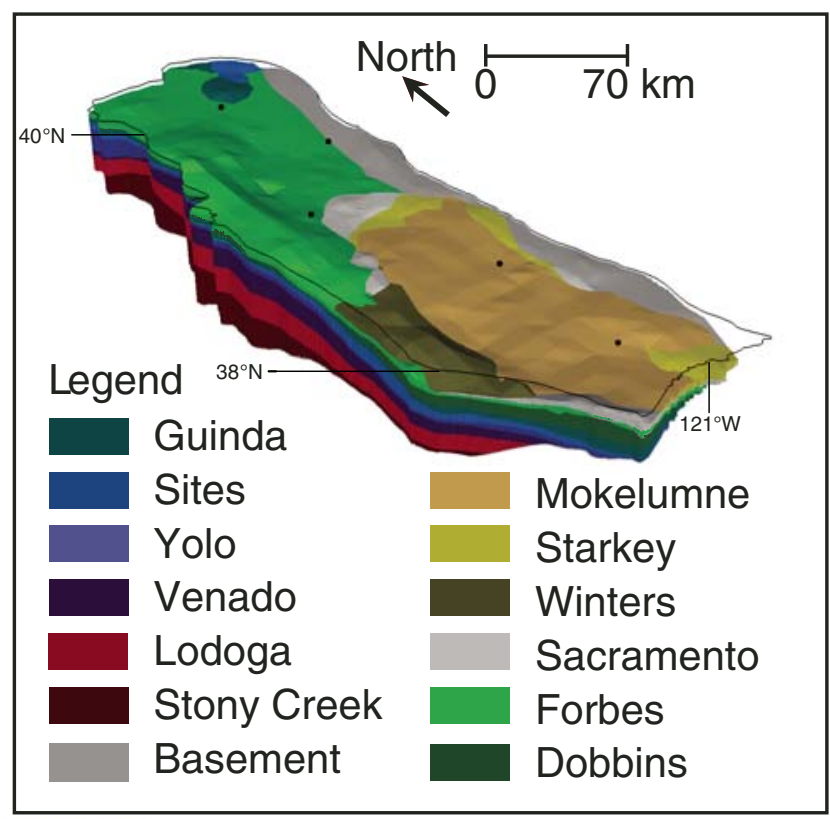

Figure 6. Oblique view of Cretaceous stratigraphy of Sacramento Basin, highlighting variability in stratal thicknesses and shift of primary depositional center in southern part of basin during CampanianMaastrichtian. Black circles are towns shown in Figure 3. 
Several geologic features were not included in the model, namely, Cenozoic paleo-submarine canyons, major faults, and western contacts with the Franciscan Complex (Supplementary Material III [see footnote 1]). In the south, thalwegs of the Paleogene Martinez, Meganos, and Markley submarine canyons incise into Maastrichtian (Meganos) and Campanian
(Markley and Martinez) strata (Almgren and Hacker, 1984). In the north, the Princeton submarine canyon incises into Coniacian/Santonian strata (Dickinson et al., 1979). As incision and infilling of these canyons occurred in the Cenozoic, they are not important for construction of primary depositional geometries in the Cretaceous (e.g., Almgren and Hacker, 1984).
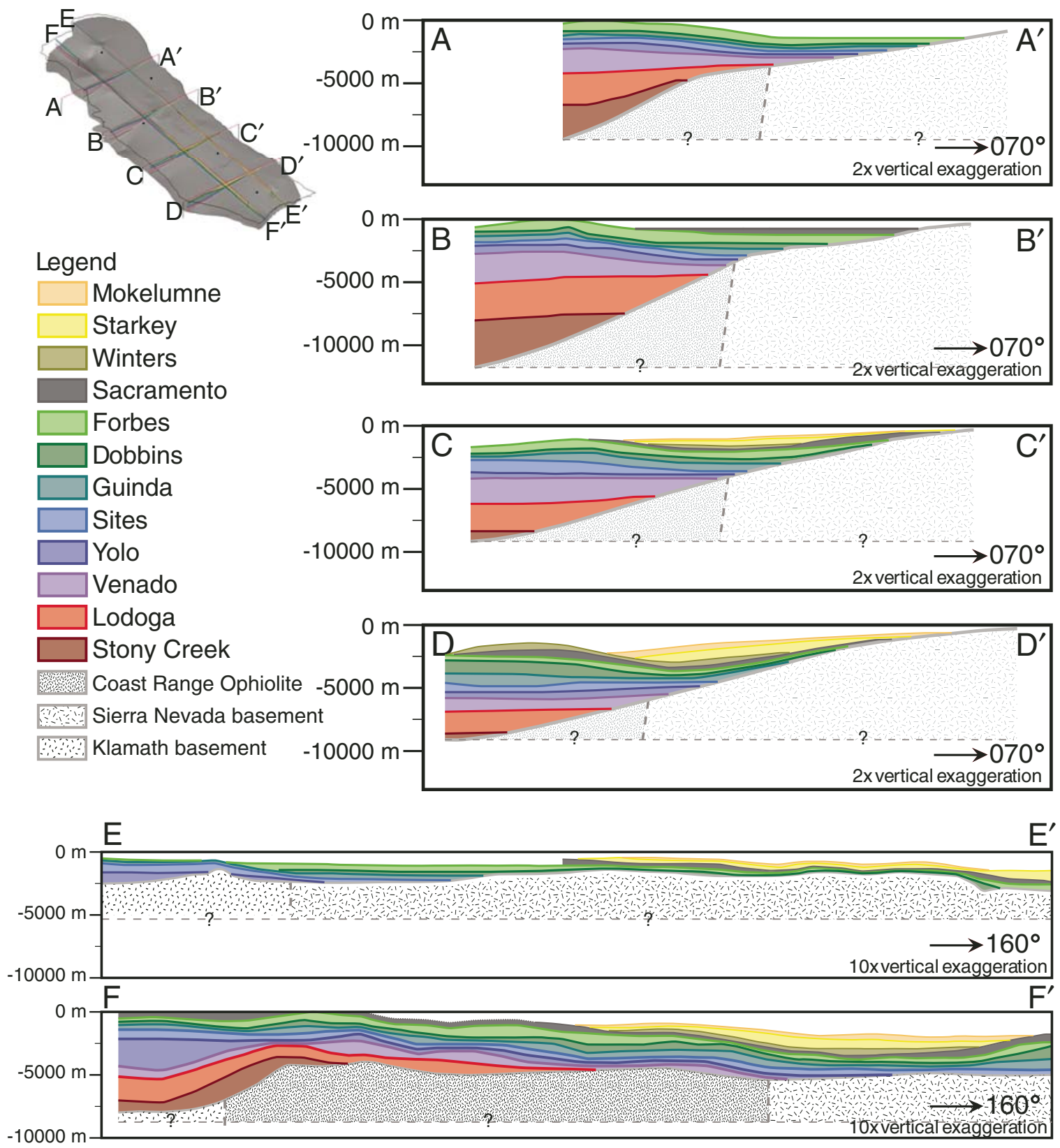

Figure 7. Cross sections of Sacramento Basin, highlighting architecture during Cretaceous deposition. (A-D) Westeast cross sections document eastward stratal onlapping onto underlying Coast Range ophiolite, and metamorphic and igneous terranes of Sierra Nevada. (E-F) North-south cross sections show migration of primary depocenter southward through time, with section F highlighting southward offlap of oldest strata. Locations of boundaries between basement terranes are based on lithologic differences of samples from borehole records and are consistent with gravity surveys, and reflection- and refraction-seismic lines. 
The Santonian Williams canyon (Williams et al., 1998), which incised into Turonian-Santonian strata along the western margin of the basin, was filled by the Dobbins and Forbes Shales and is not included in the model. Therefore, volume estimates for the Venado-Guinda units are minimum estimates, as they were partially eroded during canyon incision.

No faults were incorporated into the model, because they are, for the most part, Cenozoic and primarily restricted to the southern part of the basin (e.g., Kirby Hills or Midland fault systems). The model was constructed for areas north of the Stockton arch, although we emphasize that any correlation with the San Joaquin Basin in the future must account for offsets along this fault system. In addition, the model is unable to resolve faults that may have slipped during the Late Cretaceous and localized deposition of units such as the Winters Sandstone (e.g., Cherven, 1983; Moxon, 1990). In the northwestern part of the basin, west of Red Bluff, syndepositional normal faults are observed along the outcrop belt and in the subsurface (Moxon, 1988; Constenius et al., 2000). Our borehole distribution in this region was not sufficient to resolve and input these faults to the model, but we discuss their possible effects on stratigraphy later herein. The model does not consider possible translational faults (e.g., Wright and Wyld, 2007), as we interpret the Great Valley forearc to be autochthonous, following most workers (e.g., Dickinson and Seely, 1979; Ingersoll, 1979, 1982; Constenius et al., 2000; DeGraaff-Surpless et al., 2002). Incorporating contacts between the Franciscan Complex and Great Valley Group is beyond the scope of this study. This primarily faulted contact is timetransgressive along the strike of the outcrop belt (Ingersoll and Dickinson, 1981) and is not preserved in most areas, precluding our ability to resolve the western basin margin (Fig. 7).

\section{RESULTS}

\section{Sacramento Basin Surfaces}

A key component of our basin model is a series of structural contour maps of the surfaces of the 13 formations, from the top of basement (Jurassic) to the top of the Mokelumne River Formation (Maastrichtian; Figs. 4 and 5). Crystalline basement extends continuously from the Sierra Nevada to the outcrop belt exposed in the Coast Ranges along the western margin of the basin (Fig. 4). The depth to basement increases from east to west across the basin with a broad "shelf-like" geometry east of the longitude of Red Bluff and Sacramento, before dipping off sharply to the west to a maximum depth of $\sim 11,582 \mathrm{~m}$ $(38,000 \mathrm{ft})$ east of Williams (Fig. 4A). This sharp increase in the depth to basement is also observed in seismic-reflection line AYD-3 from Constenius et al. (2000). There are few basementpenetrating boreholes in the southwestern part of the basin, but our interpolation from the few available is consistent with a previous study for the southern part of the Sacramento Basin and interpolations from the northern San Joaquin Basin (e.g., Wentworth et al., 1995; Brabb, 2011; Scheirer, 2013). We also include a lithological map of the basement based on descriptions of basement lithology from borehole and outcrop records (Fig. 4B). Although these lithologic calls are dependent on interpretations of numerous well-site geologists, we divide the basement into three units: Coast Range ophiolite in the west, Sierra Nevada metamorphic belt and batholith in the east, and Klamath terrane to the north (Fig. 4B). The location of the boundary between the Coast Range ophiolite and Sierra Nevada metamorphic or igneous rocks is not well defined by our data set, but it is consistent with previous modeling derived from gravity anomalies, and reflection- and refraction-seismic lines, which suggest the boundary is located in the center to east-of-center part of the basin (Cady, 1975; Godfrey et al., 1997; Williams and Graham, 2013). In cross section, we draw the contact between Sierra Nevadan basement and the Coast Range ophiolite as dipping to the west, based on the crustal model of Cady (1975).

Preservation of Jurassic(?)-Lower Cretaceous strata (Stony Creek and Lodoga Formations) is limited to the western part of the basin (Fig. 5). In the subsurface, these units are found west of the town of Red Bluff or $122.5^{\circ} \mathrm{W}$ longitude, but these likely extended farther west during deposition based on remnants of forearc basin strata atop the Franciscan Complex (Dickinson and Rich, 1972; Dickinson and Seely, 1979; Ingersoll, 1982). In cross section, the northernmost surface of the Stony Creek Formation (Figs. 7A and 7F) appears parallel to subparallel with basement but rolls over at its eastern terminus. Farther south, the Stony Creek and Lodoga Formations appear to lap onto basement, but the lack of borehole data from this region prohibits a thorough geometric reconstruction.

Most of the preserved Great Valley Group accumulated during the Late Cretaceous between ca. 93 and $65 \mathrm{Ma}$; the 10 horizon maps document deposition during this time period (Fig. 5). The surfaces for the Venado, Yolo, and Sites formations (TuronianLower Coniacian) were generated from a spatially limited data set $(n \leq 21$ boreholes), but they show the greatest accumulation in the south. These formations are underlain by the Coast Range ophiolite in outcrop, but they show eastward lapping onto Sierra Nevada basement (Fig. 7). In the northernmost part of the basin, deposition of these units occurred atop Klamath basement, which, along with the northernmost Coast Range ophiolite, appears to be much deeper than the average depth to basement throughout the center of the basin at the location of this cross section (Fig. 7F). Importantly, the surface of the Venado Sandstone includes underlying Boxer Formation because the spatial limitations of the latter preclude its own surface construction.

The Guinda through Winters (Upper Coniacian-Campanian) surfaces show the development of an elongate, narrow $(<25 \mathrm{~km})$ trough in the southern part of the basin (Fig. 5). The northern part of the Sacramento Basin appears to have filled during deposition of the Kione-Forbes-Sacramento units in the Campanian, and the westernmost margin may have been above sea level (Moxon, 1988). Isopach maps indicate that within the elongate trough, maximum thicknesses of the sandstone-dominated Guinda, Forbes, and Starkey units exceeded $\sim 600 \mathrm{~m}$ during 
this time interval (Supplementary Material II [see footnote 1]). Between the late Coniacian and Maastrichtian, $>2200 \mathrm{~m}$ of sediments accumulated within this depositional center; coeval strata are absent in the north, where Eocene strata are unconformable on Campanian Kione-Forbes-Sacramento strata.

\section{Sacramento Basin Sediment Accumulation}

The mean thicknesses and volumes of each formation are summarized in Table 1. We emphasize that these are minimum values, since they were derived from compacted thicknesses, and they also do not account for the now-eroded western part of the basin. Deposited between 121 and $101 \mathrm{Ma}$, the Lodoga Formation is the thickest unit, with a mean thickness of $1028 \mathrm{~m}$ and a volume of $30,057 \mathrm{~km}^{3}$. In contrast, the thinnest unit is the Mokelumne River Formation, with a mean thickness of $170 \mathrm{~m}$ and a volume of $3267 \mathrm{~km}^{3}$. The volumetric sediment accumulation rate is variable, with rates being $<2000 \mathrm{~km}^{3} / \mathrm{m}$.y. prior to the early Turonian and between 6000 and 17,000 km $3 / \mathrm{m}$.y. from the late Turonian through the middle Campanian (Fig. 8). The Sites Sandstone saw the highest sediment accumulation rates, with $15,866 \mathrm{~km}^{3} / \mathrm{m}$.y. deposited between 86.4 and $84.0 \mathrm{Ma}$. Sediment accumulation rates during the final stages of Cretaceous deposition remained relatively constant at $\sim 1100 \mathrm{~km}^{3} / \mathrm{m}$.y.

\section{DISCUSSION}

\section{Basin Architecture}

This first 4-D basin model of the Sacramento segment of the larger Great Valley forearc basin captures its first-order geometry and sediment flux during Cretaceous deposition. The reconstructed basement surface is consistent with structural trends in the basement maps of Wentworth et al. (1995) and Scheirer et al. (2007) for the San Joaquin Basin and southern Sacramento Basin. Our surface map and cross sections show that the basement is deepest west of the town of Williams and in the northwest part of the basin. In cross section (Fig. 7A) and seismic-reflection line AYD-3 (Constenius et al., 2000), the Jurassic(?)-Lower Cretaceous Stony Creek Formation is parallel to subparallel to basement, suggesting deposition was primarily on a relatively planar basement surface. Resolving the precise angularity of onlap between the Stony Creek Formation and basement is beyond the scale of this model, but based on reflection-seismic data, Williams and Graham (2013) noted that the angularity of the nonconformity between the Great Valley Group and basement at deposition was $3^{\circ}-5^{\circ}$, similar to modern continental slopes. The westernmost north-south cross section highlights changes in the depth to basement and thickness of Stony Creek and Lodoga

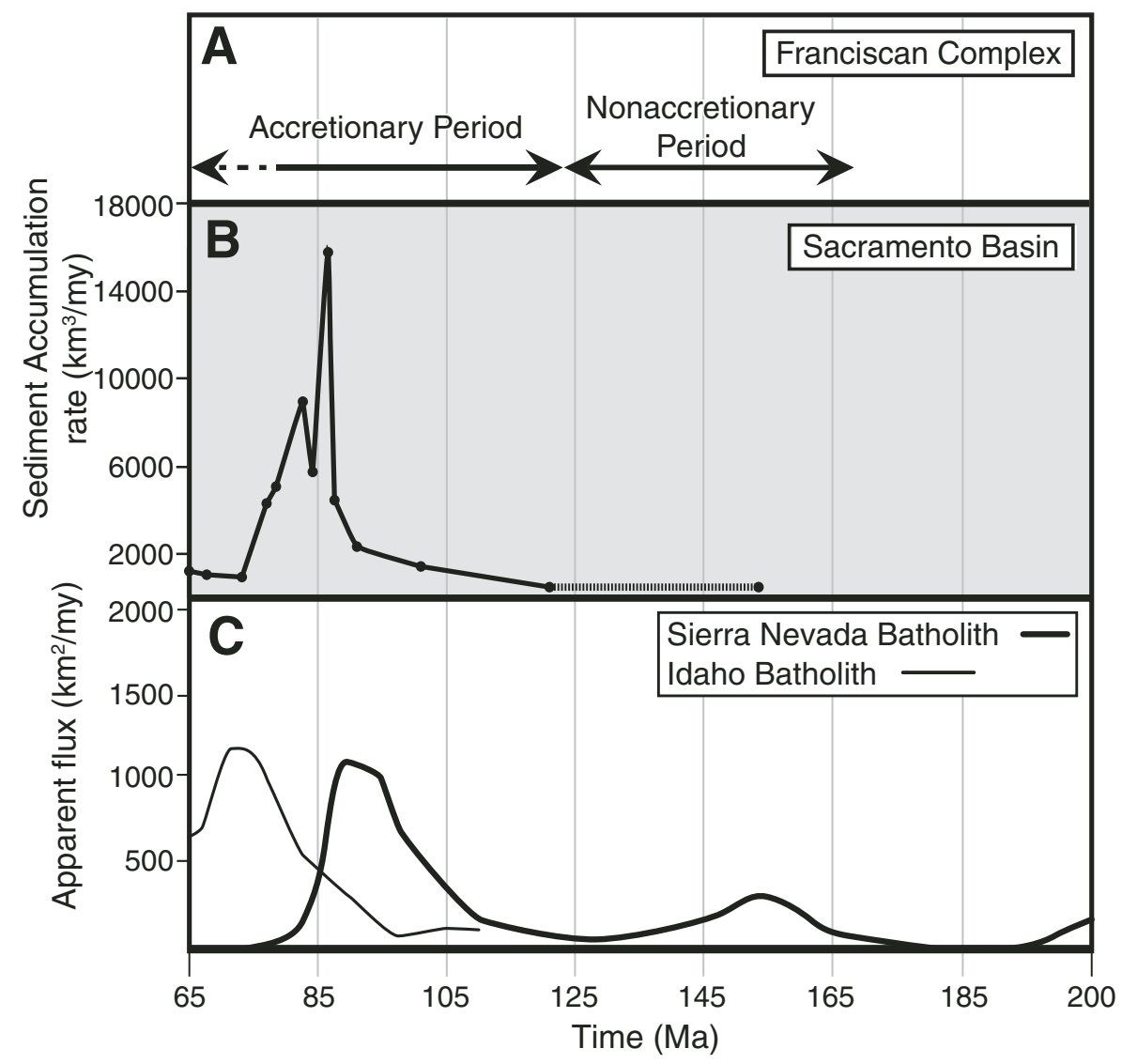

Figure 8. Comparison of accretionary history of Franciscan Complex (Dumitru et al., 2010), minimum sediment accumulation rates for Sacramento Basin (this study), and apparent magmatic flux of Sierra Nevada (Paterson and Ducea, 2015) and Idaho batholiths (Gaschnig et al., 2017). Increase in sediment accumulation rates in forearc region correlates with proposed change in Franciscan wedge from nonaccretionary to accretionary and peak in arc magmatism in Sierra Nevada. 
strata (Fig. 7F). These changes may reflect displacements along the Paskenta, Elder Creek, and Cold Fork fault zones, which are interpreted by most workers as syndepositional normal faults that omit and thicken the basal stratigraphy (Jones et al., 1969; Ingersoll, 1982; Moxon, 1988; Constenius et al., 2000). Whether these fault systems are responsible for the thickened Yolo Shale in cross section (Fig. 7F) is unclear, but we stress the thickness of the Yolo Shale at this location is controlled by one borehole pick and is not robust. Incorporating the Paskenta-Elder Creek-Cold Fork faults into the model to investigate this region further will require high-resolution seismic-reflection data, which may be available in the future.

Although there are limited borehole data in the northern and western edges of the basin, relative to central parts, construction of the model revealed some details in these regions. Along the western margin of the basin, reconstructed paleodepths of outcrop strata by Moxon $(1988,1990)$ and Williams $(1997,1998)$ suggested development of a topographic/bathymetric "ridge" initiating as early as the Turonian-Coniacian and fully developing by the late Campanian (Fig. 5). This topographic feature is suggested by the shallow depths (blue color) along the western margin of the basin, defined best by the Campanian Dobbins and Forbes surfaces (Fig. 5). This ridge, which is also controlled by borehole picks from this study just east of the outcrop belt, forms a linear feature in the northern part of the basin. Observed in cross section (Fig. 7B), it appears that Forbes, Dobbins, Guinda, and Sites strata are uplifted and dipping eastward from this feature, albeit subtly at the scale of the model. Overlying units have variable thicknesses locally east of this feature. Although we limit our interpretation of this feature based on the few borehole picks available from this region, seismic-reflection lines restored to Cretaceous configuration from Constenius et al. (2000) highlight Cretaceous reflections with eastward dip (e.g., figure 8 in Constenius et al. 2000). Therefore, it is plausible that this feature represents backtilting of forearc strata during growth of the Franciscan accretionary wedge. This type of geometry is observed along seaward margins of other forearc basins, such as offshore Chile and Alaska (Williams and Graham, 2013; Noda, 2016).

Our model shows the overall southward migration of the primary depositional center along the partially preserved western limit and central part of the basin (Fig. 7), a feature previously noted by Moxon (1990). These results are consistent with paleocurrent data from the western outcrop belt that show southerly and westerly paleoflow directions (Ingersoll, 1979). In addition, the basin-filling pattern is consistent with outcrop stratigraphy, which shows southward deepening from upper-slope mudstone through slope channels to thick-bedded incised midfan and unconfined-fan-lobe deposits during the Turonian to early Campanian (Ingersoll, 1976). The margins of the southern depositional center, commonly referred to as the Delta depositional center (Zieglar and Spotts, 1978), are difficult to reconstruct owing to the presence of the Cenozoic Kirby Hills and Midland fault zones along the western margin of the basin (Fig. 5). Accommodation during deposition of the Winters, Starkey, and Moke- lumne River units was likely controlled by local faulting along the western terminus of the trough (Cherven, 1983; Moxon, 1990). However, the scale of the model prohibits individual well correlations, which are necessary to define the western margin of these units. Future work will seek to incorporate these faults, as well as overlying Cenozoic strata that contain easily identifiable shale horizons, to quantify the effects of Cenozoic motion along trough-bounding faults on primary basin geometry.

Geometric relationships along the east side of the basin show onlap of Sierra Nevada basement, the dip of which appears to steepen from horizontal in the north to $5^{\circ}-10^{\circ}$ for Santonian-Maastrichtian (Guinda-Mokelumne) strata in the south (Figs. 7A-7D). This onlap architecture is consistent with paleobathymetric profiles from the middle Turonian to Santonian, which show overall eastward retrogradation (e.g., Williams, 1997). Previous work on subsurface stratigraphy along the eastern margin of the basin detailed transgressive sequences, with deposition occurring in sublittoral to outer-neritic zones (e.g., Haggart and Ward, 1984). Paleobathymetric studies also support our conclusion that the northern Sacramento Basin filled by early Campanian time (i.e., Forbes-Kione deposition), whereas the southern part of the basin retained marine to deltaic depositional environments until the latest Maastrichtian (Williams, 1997).

\section{Forearc Basin Sediment Flux}

Sediment fluxes were variable in the Great Valley forearc basin during the Cretaceous, as noted by Williams and Graham (2013) and DeCelles and Graham (2015), with deposition of the Sites Sandstone marking a drastic change in sediment input in the Turonian to Coniacian. Importantly, these rates are based on minimum volume determinations, as strata have not been decompacted. These minimum volumes and rates will be rectified in our future work, which will use this model as the foundation for a geohistory analysis. In addition, the rates are a function of our age assignments (Fig. 2). This is especially important for calculation of sediment flux for the Stony Creek Formation at the initiation of forearc deposition. We assign an age of ca. $153 \mathrm{Ma}$ for the start of deposition, based on the general age assignment of Kimmeridgian for the basement (e.g., Shervais et al., 2005). However, the age of the basement varies along strike, as it does in many forearc systems (e.g., Noda, 2016; Orme and Laskowski, 2016), and the age of the basal Stony Creek is uncertain (Surpless et al., 2006). If the initial depositional age is as young as ValanginianHauterivian (Surpless et al., 2006), then it could increase sedimentation rates by an order of magnitude. Regardless of these uncertainties, much of the Stony Creek Formation was presumably removed during Cenozoic shortening (Dickinson and Seely, 1979; Ingersoll and Dickinson, 1981; Ingersoll, 1982), and flux estimates are therefore minima. In addition, the volume estimate for deposition ca. $78-77 \mathrm{Ma}$ is a minimum, because it does not include the stratigraphy of the Kione delta. Nevertheless, sedimentation rates from this study are consistent with average rates from detailed work on the western outcrop, where accumulation 
rates peaked in the Turonian and Coniacian, followed by a general decrease through the remainder of the Cretaceous (Ingersoll, 1979). Peak sedimentation rates occurred prior to the estimated time of gas generation in the Sacramento Basin, with the first period of thermal maturation occurring at 80-70 Ma (Zieglar and Spotts, 1978). Previous work interpreted the decrease in sedimentation rates following Turonian time to reflect wider dispersal of available sediment as the basin increased in dimension (Ingersoll, 1979) and an overall decrease in sediment supply during Late Cretaceous time as volcanic and plutonic activity in magmatic source regions lessened (Ingersoll, 1978, 1982).

Sediment accumulation rates correlate well with the apparent flux of magmatic activity in the Sierra Nevada magmatic arc (Fig. 8). During deposition of Cretaceous forearc basin strata, the Sierra Nevada arc experienced high-flux magmatism between 125 and $85 \mathrm{Ma}$, with the peak being between 100 and $90 \mathrm{Ma}$ (Paterson and Ducea, 2015). The peak in sedimentation within the forearc is slightly younger (ca. 86-78 Ma), likely reflecting the residence time from pluton emplacement to deposition in the neighboring forearc basin (Fig. 8). This result is consistent with the short lag times between U-Pb crystallization ages and depositional ages in the Great Valley forearc, which yield unroofing rates of the southern and western Sierra Nevada of $0.35-1 \mathrm{~mm} / \mathrm{yr}$ (DeGraaff-Surpless et al., 2002) and high average erosion rates of 0.4-0.7 mm/yr (Ague and Brimhall, 1988) during the Cretaceous. Similarly, exhumation rates of $0.5-1 \mathrm{~mm} / \mathrm{yr}$ of the central Sierra Nevada (Vermeesch et al., 2006) and uplift rates of the southern Sierra Nevada of 0.5-1.2 mm/yr (Sams and Saleeby, 1988; Pickett and Saleeby, 1993) are consistent with short lag times between pluton emplacement and deposition. The observed flux in peak magmatism of the Idaho batholith (Gaschnig et al., 2017) does not show a strong correlation with the Cretaceous flux curve from the Sacramento Basin. However, detrital-zircon provenance studies of Eocene Great Valley forearc strata show that the Idaho batholith was a significant source of material from 57 to $53 \mathrm{Ma}$ (Dumitru et al., 2012). Therefore, we hypothesize that expansion of our model into the Cenozoic might reveal a second peak in sediment accumulation related to a period of high-flux magmatism and erosion of the Idaho batholith.

Sediment accumulation rates in the Sacramento Basin correlate to phases of activity in the Franciscan Complex (Fig. 8). Dumitru et al. (2010) and DeCelles and Graham (2015) argued for the transition from a nonaccretionary forearc margin to an accretionary margin at ca. $123 \mathrm{Ma}$. This was based primarily on geochronologic ages from the South Fork Mountain Schist, which is interpreted as the first unit of significant size to accrete into the Franciscan wedge (Dumitru et al., 2010). This time period corresponds to the end of deposition of the Stony Creek Formation and a steady increase in sediment accumulation rates thereafter. We suggest that prior to the Franciscan Complex becoming truly accretionary, there was no outer forearc high to trap significant volumes of sediment in the Great Valley forearc region (Ingersoll, 1982). Any sediment that accumulated along the margin during the interpreted nonaccretionary period was likely subducted. The mechanism driving the change from nonaccretionary to accretionary margin, which coincided with an increase in sediment accumulation rates in the Great Valley forearc, is poorly understood. As this work reports, the increase in sedimentation rates correlates with a magmatic flare-up of the Sierra magmatic arc, which may have resulted in increased erosion rates to the forearc region (cf., DeCelles and Graham, 2015). Dumitru et al. (2012) hypothesized that a change in drainage systems of major rivers, similar to the modern Cascadia forearc, may have increased sediment supply to the trench and forearc. DeGraaff-Surpless et al. (2002) demonstrated that the Sites Sandstone was derived locally from the western Sierra metamorphic belt, which formed a drainage divide in the midCretaceous. Therefore, unlike some Cenozoic river systems sourced from the continental interior that crosscut the Sierra Nevada batholith to deliver sediment to the Great Valley forearc (e.g., Cassel et al., 2012), the increase in sediment supply to the Great Valley from rivers in the Cretaceous reflects a response to local changes in erosion rate along the west side of the arc drainage divide (Linn, 1991; Linn et al., 1991).

The minimum sediment accumulation rates determined in this study are similar to un-decompacted sedimentation rates calculated for other forearc basins. Direct comparison of sedimentation rates of basal forearc sedimentary sequences is challenging because they range widely, from $<15 \mathrm{~m} / \mathrm{m}$.y. to $>800 \mathrm{~m} / \mathrm{m}$.y. (e.g., Underwood et al., 1995). However, comparison of peak sedimentation rates between forearc basins reveals some interesting similarities. Sedimentation rates in the intraoceanic IzuBonin forearc basin were 100-300 m/m.y. in Oligocene time, i.e., less than the peak rates calculated in this study (Turonian Sites Sandstone, $475 \mathrm{~m} / \mathrm{m} . \mathrm{y}$.) and from the Great Valley forearc outcrop belt (425 m/m.y.; Ingersoll, 1979). As discussed in Underwood et al. (1995), similar rates between intraoceanic and continental forearc systems are surprising, considering major differences in the grain size of basal forearc fill, sandstone bed thickness, and stratigraphic architecture of turbidite-fan systems. In addition, many forearc basins, regardless of whether they develop along a continental margin or in an intraoceanic setting, record rapid rates of sedimentation early in their histories, followed by a general decrease through time (e.g., Underwood et al., 1995). This is observed in systems such as, but not limited to, the Izu-Bonin intraoceanic forearc system (Underwood et al., 1995), the Xigaze forearc basin system in southern Tibet (Orme et al., 2015), and the Tonga forearc basin (Underwood et al., 1995). Similar to the Great Valley forearc basin, sedimentation rates from the Xigaze and Tonga forearc basins show strong correlation with magmatic flux, whereby periods of high-flux magmatism correspond to periods of rapid sediment accumulation, and periods of low sedimentation correspond to a decrease or lull in arc magmatism (Underwood et al., 1995; Orme et al., 2015). Future decompaction analyses will allow for direct comparison of the Great Valley forearc with other forearc basins, but the correlation between sedimentation rate and magmatic flux appears to be a first-order feature of forearc basin systems. 


\section{CONCLUSIONS}

This study presents the first 4-D model of the northern Great Valley forearc basin, including the first complete map of forearc basement throughout the Sacramento Basin. The model captures the southward migration of the locus of deposition during the Cretaceous, as well as the eastward lap out of strata onto Sierran arc basement, reflecting an overall eastward shoreline transgression. The use of this model for petroleum-systems modeling must incorporate deformation related to Cenozoic faults, and erosion and filling of paleocanyons, but it provides the foundation for more detailed modeling of subregions of the basin. This quantification of the changes in sediment accumulation through time and space provides the foundation with which to investigate controls on basin subsidence in four dimensions, which will be the focus of future research.

\section{ACKNOWLEDGMENTS}

This project was funded by the School of Earth, Energy and Environmental Sciences at Stanford University, with aid from the Stanford Project on Deep-water Depositional Systems (SPODDS) and Basin and Petroleum System Modeling Group (BPSM) consortia. We thank Allegra Hosford Scheirer and Kurt Constenius for initial identification of many Sacramento Valley boreholes and informative discussions. We acknowledge the use of the Move ${ }^{\mathrm{TM}}$ Software Suite granted by Midland Valley's Academic Software Initiative and Andrew Laskowski for guidance with the model construction in Move ${ }^{\mathrm{TM}}$. We thank Jeffrey Trop and Jacob Covault for detailed and insightful reviews, and Editors Raymond Ingersoll and Richard Davis for professional handling of this manuscript.

\section{REFERENCES CITED}

Ague, J.J., and Brimhall, G.H., 1988, Magmatic arc asymmetry and distribution of anomalous plutonic belts in batholiths of California: Effects of assimilation, crustal thickness, and depth of crystallization: Geological Society of America Bulletin, v. 100, p. 912-927, https://doi.org/10.1130/0016 -7606(1988)100<0912:MAAADO>2.3.CO;2.

Almgren, A.A., 1984, Timing of Tertiary submarine canyons and marine cycles of deposition in the southern Sacramento Valley, California, in Almgren, A.A., and Hacker, P.D., eds., Paleogene Submarine Canyons of the Sacramento Valley, California: Bakersfield, California, Pacific Section, American Association of Petroleum Geologists, p. 1-16.

Almgren, A.A., 1986, Benthic foraminiferal zonation and correlations of Upper Cretaceous strata of the Great Valley of California-A modification, in Abbott, P.L., ed., Cretaceous Stratigraphy, Western North America: Society of Economic Paleontologists and Mineralogists, Pacific Section, Book 46, p. 37-152.

Almgren, A.A., and Hacker, P.D., eds., 1984, Paleogene Submarine Canyons of the Sacramento Valley, California: Bakersfield, California, Pacific Section, American Association of Petroleum Geologists, Symposium Volume $1,187 \mathrm{p}$.

Berry, K.D., 1974, Mesozoic foraminiferal zonation, Turonian to Tithonian Stages, Pacific Coast Province, in Annual Meeting Proceedings: Bakersfield, California, Society of Economic Paleontologists and Mineralogists, Pacific Section, p. 1-29.

Brabb, E.E., 2011, Location and Age of Foraminifer Samples Examined by Chevron Petroleum Company Paleontologists from More than 2,500 Oil
Test Wells in California: U.S. Geological Survey Open-File Report 2011$1262,4 \mathrm{p}$.

Cady, J.W., 1975, Magnetic and Gravity Anomalies in the Great Valley and Western Sierra Nevada Metamorphic Belt, California: Geological Society of America Special Paper 168, 56 p., https://doi.org/10.1130/SPE168-p1.

Cassel, E.J., Graham, S.A., Chamberlain, C.P., and Henry, C.D., 2012, Early Cenozoic topography, morphology, and tectonics of the northern Sierra Nevada and western Basin and Range: Geosphere, v. 8, p. 229-249, https://doi.org/10.1130/GES00671.1.

Cherven, V.B., 1983, Stratigraphy, facies, and depositional provinces of the middle Eocene Domengine Formation, southern Sacramento Basin, in Cherven, V.B., and Graham, S.A., eds., Geology and Sedimentology of Southwestern Sacramento Basin and East Bay Hills: Pacific Section, SEPM, p. 63-72.

Clift, P.D., and Vannucchi, P., 2004, Controls on tectonic accretion versus erosion in subduction zones: Implications for the origin and recycling of the continental crust: Reviews of Geophysics, v. 42, RG2001, https://doi .org/10.1029/2003RG000127.

Constenius, K.N., Johnson, R.A., Dickinson, W.R., and Williams, T.A., 2000, Tectonic evolution of the Jurassic-Cretaceous Great Valley forearc, California: Implications for the Franciscan thrust-wedge hypothesis: Geological Society of America Bulletin, v. 112, p. 1703-1723, https://doi .org/10.1130/0016-7606(2000)112<1703:TEOTJC>2.0.CO;2.

DeCelles, P.G., 2004, Late Jurassic to Eocene evolution of the Cordilleran thrust belt and foreland basin system, western U.S.A.: American Journal of Science, v. 304, p. 105-168, https://doi.org/10.2475/ajs.304.2.105.

DeCelles, P.G., and Graham, S.A., 2015, Cyclical processes in the North American Cordilleran orogenic system: Geology, v. 43, p. 499-502, https://doi org/10.1130/G36482.1.

DeGraaff-Surpless, K., Graham, S.A., Wooden, J.L., and McWilliams, M.O., 2002, Detrital zircon provenance analysis of the Great Valley Group, California: Evolution of an arc-forearc system: Geological Society of America Bulletin, v. 114, p. 1564-1580, https://doi.org/10.1130/0016 -7606(2002)114<1564:DZPAOT>2.0.CO;2.

Dickinson, W.R., 1970, Relations of andesites, granites and derivative sandstone to arc-trench tectonics: Reviews of Geophysics and Space Physics, v. 8, p. 813-886, https://doi.org/10.1029/RG008i004p00813.

Dickinson, W.R., 1995, Forearc basins, in Busby, C.J., and Ingersoll, R.V., eds., Tectonics of Sedimentary Basins: Cambridge, Massachusetts, Blackwell Science, p. 221-261.

Dickinson, W.R., and Rich, E.I., 1972, Petrologic intervals and petrofacies in the Great Valley sequence, Sacramento Valley, California: Geological Society of America Bulletin, v. 83, p. 3007-3024, https://doi.org/10.1130/0016 -7606(1972)83[3007:PIAPIT]2.0.CO;2.

Dickinson, W.R., and Seely, D.R., 1979, Structure and stratigraphy of forearc regions: American Association of Petroleum Geologists Bulletin, v. 63, p. $2-31$.

Dickinson, W.R., and Snyder, W.S., 1978, Plate tectonics of the Laramide orogeny, in Matthews, V., III, ed., Laramide Folding Associated with Basement Block Faulting in the Western United States: Geological Society of America Memoir 151, p. 355-366, https://doi.org/10.1130/MEM151-p355.

Dickinson, W.R., Ingersoll, R.V., and Graham, S.A., 1979, Paleogene sediment dispersal and paleotectonics in northern California: Geological Society of America Bulletin, v. 90, no. 10, pt. II, p. 1458-1528, https://doi .org/10.1130/GSAB-P2-90-1458.

Dickinson, W.R., Armin, R.A., Beckvar, N., Goodlin, T.C., Janecke, S.U., Mark, R.A., Norris, R.D., Radel, G., and Wortman, A.A., 1987, Geohistory analysis of rates of sediment accumulation and subsidence for selected California basins, in Ingersoll, R.V., and Ernst, W.G., eds., Cenozoic Basin Development of Coastal California: Englewood Cliffs, New Jersey, Prentice-Hall, p. 1-23.

Shepard, D., 1968, A two-dimensional interpolation function for irregularlyspaced data: Proceedings of the 1968 ACM National Conference, New York, 27-29 August 1968, p. 517-524, https://doi.org/10.1145/ 800186.810616 .

Ducea, M., 2001, The California arc: Thick granitic batholiths, eclogitic residues, lithospheric-scale thrusting, and magmatic flare-ups: GSA Today, v. 11, no. 11, p. 4-10, https://doi.org/10.1130/1052-5173(2001)011<0004:TCA TGB $>2.0 . \mathrm{CO} ; 2$.

Dumitru, T.A., Wakabayashi, J., Wright, J.E., and Wooden, J.L., 2010, Early Cretaceous transition from nonaccretionary behavior to strongly 
accretionary behavior within the Franciscan subduction complex: Tectonics, v. 29, TC5001, https://doi.org/10.1029/2009TC002542.

Dumitru, T.A., Ernst, W.G., Wright, J.E., Wooden, J.L., Wells, R.E., Farmer, L.P., Kent, A.J.R., and Graham, S.A., 2012, Eocene extension in Idaho generated massive sediment floods into the Franciscan trench and into the Tyee, Great Valley, and Green River basins: Geology, v. 41, p. 187-190, https://doi.org/10.1130/G33746.1.

Dumitru, T.A., Elder, W.P., Hourigan, J.K., Chapman, A.D., Graham, S.A., and Wakabayashi, J., 2015, Four Cordilleran paleorivers that connected Sevier thrust zones in Idaho to depocenters in California, Washington, Wyoming, and indirectly, Alaska: Geology, v. 44, p. 75-78, https://doi.org/10.1130/ G37286.1.

Ernst, W.G., 1970, Tectonic contact between the Franciscan mélange and the Great Valley sequence: Crustal expression of a late Mesozoic Benioff zone: Journal of Geophysical Research, v. 75, p. 886-901, https://doi .org/10.1029/JB075i005p00886.

Environmental Systems Research Institute (ESRI), 2016, ArcGIS Desktop: Release 10.6. Redlands, California, Environmental Systems Research Institute.

Gaschnig, R.M., Vervoort, J.D., Tikoff, B., and Lewis, R.S., 2017, Construction and preservation of batholiths in the northern U.S. Cordillera: Lithosphere, v. 9, p. 315-324, https://doi.org/10.1130/L497.1.

Godfrey, N.J., Beaudoin, B.C., and Klemperer, S.L., and Mendocino Working Group, 1997, Ophiolitic basement to the Great Valley forearc basin, California, from seismic and gravity data: Implications for crustal growth at the North American continental margin: Geological Society of America Bulletin, v. 109, no. 12, p. 1536-1562, https://doi.org/10.1130/0016 -7606(1997)109<1536:OBTTGV>2.3.CO;2.

Goudkoff, P.P., 1945, Stratigraphic relations of Upper Cretaceous in Great Valley, California: American Association of Petroleum Geologists Bulletin, v. 29 , p. $956-1007$.

Graham, S.A., 1981, Stratigraphic and depositional patterns and hydrocarbon occurrence, Sacramento Valley, California, in Graham, S.A., ed., Field Guide to the Mesozoic-Cenozoic Convergent Margin of Northern California: Bakersfield, California, Pacific Section, American Association of Petroleum Geologists, Book 50, p. 43-58.

Graham, S.A., 1987, Tectonic controls on petroleum occurrence in central California, in Ingersoll, R.V., and Ernst, W.G., eds., Cenozoic Basin Development of Coastal California: Englewood Cliffs, New Jersey, Prentice-Hall, p. 47-63.

Graham, S.A., Stanley, R.G., Bent, J.V., and Carter, J.B., 1989, Oligocene and Miocene paleogeography of central California and displacement along the San Andreas fault: Geological Society of America Bulletin, v. 101, p. 711-730, https://doi.org/10.1130/0016-7606(1989)101<0711 :OAMPOC $>2.3 . \mathrm{CO} ; 2$.

Hackel, O., 1966, Summary of the geology of the Great Valley, in Bailey, E.H., ed., Geology of Northern California: California Division of Mines and Geology Bulletin 190, p. 217-238.

Haggart, J.W., and Ward, P.D., 1984, Late Cretaceous (Santonian-Campanian) stratigraphy of the northern Sacramento Valley, California: Geological Society of America Bulletin, v. 95, p. 618-627, https://doi .org/10.1130/0016-7606(1984)95<618:LCSSOT>2.0.CO;2.

Ingersoll, R.V., 1976, Evolution of the Late Cretaceous Forearc Basin of Northern and Central California [Ph.D. thesis]: Stanford, California, Stanford University, $200 \mathrm{p}$.

Ingersoll, R.V., 1978, Petrofacies and petrologic evolution of the Late Cretaceous fore-arc basin, northern and central California: The Journal of Geology, v. 86, p. 335-352, https://doi.org/10.1086/649695.

Ingersoll, R.V., 1979, Evolution of the Late Cretaceous forearc basin, northern and central California: Geological Society of America Bulletin, v. 90, p. 813-826, https://doi.org/10.1130/0016-7606(1979)90<813:EOTLCF $>2.0 . \mathrm{CO} ; 2$.

Ingersoll, R.V., 1982, Initiation and evolution of the Great Valley forearc basin of northern and central California, U.S.A., in Leggett, J.K., ed., TrenchForearc Geology: Sedimentation and Tectonics on Modern and Ancient Active Plate Margins: Geological Society, London, Special Publication 10, p. 459-467, https://doi.org/10.1144/GSL.SP.1982.010.01.31.

Ingersoll, R.V., 2012, Tectonics of sedimentary basins, with revised nomenclature, in Busby, C., and Azor-Perez, A., eds., Tectonics of Sedimentary Basins: Recent Advances: Oxford, UK, Blackwell, p. 3-43.

Ingersoll, R.V., and Dickinson, W.R., 1981, Great Valley Group (sequence), Sacramento Valley, California, in Frizzell, V., ed., Upper Mesozoic
Franciscan Rocks and Great Valley Sequence, Central Coast Ranges, California: Bakersfield, California, Pacific Section, Society of Economic Paleontologists and Mineralogists, Annual Meeting 1981 Guidebook, Field Trips 1 and 4, p. 1-33.

Jones, D.L., Bailey, E.H., and Imlay, R.W., 1969, Structural and Stratigraphic Significance of the Buchia Zones in the Colyear Springs-Paskenta Area, California: U.S. Geological Survey Professional Paper 647-A, 24 p.

Linn, A.M., 1991, Isotopic and Geochemical Stratigraphy and Paleotectonic Analysis: Mesozoic Great Valley Forearc Basin of California [Ph.D. thesis]: Los Angeles, California, University of California, 133 p.

Linn, A.M., DePaolo, D.J., and Ingersoll, R.V., 1991, Nd-Sr isotopic provenance analysis of Upper Cretaceous Great Valley forearc sandstones: Geology, v. 19, p. 803-806, https://doi.org/10.1130/0091 -7613(1991)019<0803:NSIPAO >2.3.CO;2.

Mitchell, C., Graham, S.A., and Suek, D.H., 2010, Subduction complex uplift and exhumation and its influence on Maastrichtian forearc stratigraphy in the Great Valley Basin, northern San Joaquin Valley, California: Geological Society of America Bulletin, v. 122, p. 2063-2078, https://doi .org/10.1130/B30180.1.

Morrison, R.R., Brown, W.R., Edmonson, W.F., Thomson, J.N., and Young, R.J., 1971, Potential of Sacramento Valley gas province, California, in Cram, I.H., ed., Future Petroleum Provinces of the United States-Their Geology and Potential: American Association of Petroleum Geologists Memoir 15, p. 329-338.

Moxon, I.W., 1988, Sequence stratigraphy of the Great Valley basin in the context of convergent margin tectonics, in Graham, S.A., ed., Studies of the Geology of the San Joaquin Basin: Bakersfield, California, Pacific Section, Society of Economic Paleontologists and Mineralogists, Field Trip Guidebook 60, p. 3-28.

Moxon, I.W., 1990, Stratigraphic and Structural Architecture of the San Joaquin-Sacramento Basin [Ph.D. thesis]: Stanford, California, Stanford University, $371 \mathrm{p}$.

Nilsen, T.H., 1990, Santonian, Campanian, and Maastrichtian depositional systems, Sacramento basin, California, in Ingersoll, R.V., and Nilsen, T.H. eds., Sacramento Valley Symposium and Guidebook: Bakersfield, California, Pacific Section, Society of Economic Paleontologists and Mineralogists, Book 65, p. 95-132.

Noda, A., 2016, Forearc basins: Types, geometries, and relationships to subduction zone dynamics: Geological Society of America Bulletin, v. 128, p. 879-895, https://doi.org/10.1130/B31345.1.

Orme, D.A., and Laskowski, A.K., 2016, Basin analysis of the Albian-Santonian Xigaze forearc, south-central Tibet: Journal of Sedimentary Research, v. 86, p. 894-913, https://doi.org/10.2110/jsr.2016.59.

Orme, D.A., Carrapa, B., and Kapp, P., 2015, Sedimentology, provenance, and geochronology of the Upper Cretaceous-Lower Eocene western Xigaze forearc basin, southern Tibet: Basin Research, v. 27, p. 387-411, https:// doi.org/10.1111/bre.12080.

Paterson, S.R., and Ducea, M.N., 2015, Arc magmatic tempos: Gathering the evidence: Elements, v. 11, no. 2, p. 91-98, https://doi.org/10.2113/ gselements.11.2.91.

Pickett, D.A., and Saleeby, J.B., 1993, Thermobarometric constraints on the depth of exposure and conditions of plutonism and metamorphism at deep levels of the Sierra Nevada batholith, Tehachapi Mountains, California: Journal of Geophysical Research, v. 98, p. 609-629, https://doi .org/10.1029/92JB01889.

Posamentier, H.W., Davies, R.J., Cartwright, J.A., and Wood, L., 2007, Seismic geomorphology-An overview, in Davies, R.J., Posamentier, H.W., Wood, L.J., and Cartwright, J.A., eds., Seismic Geomorphology: Applications to Hydrocarbon Exploration and Production: Geological Society, London, Special Publication 277, p. 1-14, https://doi.org/10.1144/GSL SP.2007.277.01.01.

Sams, D.B., and Saleeby, J.B., 1988, Geology and petro-tectonic significance of crystalline rocks of the southernmost Sierra Nevada, California, in Ernst, W.G., ed., Metamorphism and Crustal Evolution of the Western United States [Rubey Volume VII]: Englewood Cliffs, New Jersey, Prentice-Hall, p. $865-893$

Scheck, M., and Bayer, U., 1999, Evolution of the northeast German Basin: Inferences from a 3D structural model and subsidence analysis: Tectonophysics, v. 313, p. 145-169, https://doi.org/10.1016/S0040-1951 (99)00194-8.

Scheirer, A.H., 2013, The three-dimensional geologic model used for the 2003 National Oil and Gas Assessment of the San Joaquin Basin Province, 
California, Petroleum Systems and Geologic Assessment of Oil and Gas in the San Joaquin Basin Province, California: U.S. Geological Survey Professional Paper 1713, 81 p.

Scheirer, A.H., Tennyson, M.E., Magoon, L.B., Charpentier, R.R., Cook, T.A., Klett, T.R., Pollastro, R.M., and Schenk, C.J., 2007, Assessment of Undiscovered Natural Gas Resources of the Sacramento Basin Province of California, 2006: U.S. Geological Survey Fact Sheet 2007-3014, 2 p.

Sharman, G.R., Graham, S.A., Grove, M., Kimbrough, D.L., and Wright, J.E., 2014, Detrital zircon provenance of the Late Cretaceous-Eocene California forearc: Influence of Laramide low-angle subduction on sediment dispersal and paleogeography: Geological Society of America Bulletin, v. 127, p. 38-60, https://doi.org/10.1130/B31065.1.

Shervais, J.W., Murchey, B.L., Kimbrough, D.L., Renne, P.R., and Hanan, B. 2005, Radioisotopic and biostratigraphic age relations in the Coast Range ophiolite, northern California: Implications for the tectonic evolution of the Western Cordillera: Geological Society of America Bulletin, v. 117 p. 633-653, https://doi.org/10.1130/B25443.1.

Surpless, K.D., Graham, S.A., Covault, J.A., and Wooden, J.L., 2006, Does the Great Valley Group contain Jurassic strata? Reevaluation of the age and early evolution of a classic forearc basin: Geology, v. 34, p. 21-24, https:// doi.org/10.1130/G21940.1.

Underwood, M.B., Balance, P.F., Clift, P.D., Hiscott, R.N., Marsaglia, K.M., Pickering, K.T., and Reid, R.P., 1995, Sedimentation in forearc basins, trenches, and collision zones of the western Pacific: A summary of results from the Ocean Drilling Program, in Taylor, B., and Natland, J., eds., Active Margins and Marginal Basins of the Western Pacific: American Geophysical Union Geophysical Monograph 88, p. 315-353.

Unruh, J.R., Loewen, B.A., and Morres, E.M., 1995, Progressive arcward contraction of a Mesozoic-Tertiary forearc basin, southwestern Sacramento Valley, California: Geological Society of America Bulletin, v. 107, p. 38-53, https://doi.org/10.1130/0016-7606(1995)107<0038:PACOAM $>2.3 . \mathrm{CO} ; 2$.

Vermeesch, P., Miller, D.D., Graham, S.A., Grave, J.D., and McWilliams, M.O., 2006, Multimethod detrital thermochronology of the Great Valley Group near New Idria, California: Geological Society of America Bulletin, v. 118, p. 210-218, https://doi.org/10.1130/B25797.1.
Wakabayashi, J., 2015, Anatomy of a subduction complex: Architecture of the Franciscan Complex, California, at multiple length and time scales: International Geology Review, v. 57, p. 669-746, https://doi.org/10.1080/ 00206814.2014 .998728

Walker, J.D., Geissman, J.W., Bowring, S.A., and Babcock, L.E., compilers, 2012, Geologic Time Scale, Version 4.0: Boulder, Colorado, Geological Society of America, https://doi.org/10.1130/2012.CTS004R3C.

Wentworth, C.M., Fisher, G.R., Levine, P., and Jachens, R.C., 1995, The Surface of Crystalline Basement, Great Valley and Sierra Nevada, California: A Digital Map Database: U.S. Geological Survey Open-File Report 95-96, $18 \mathrm{p}$.

Williams, T.A., 1997, Basin-Fill Architecture and Forearc Tectonics, Cretaceous Great Valley Group, Sacramento Basin, Northern California [Ph.D. thesis]: Stanford, California, Stanford University, $412 \mathrm{p}$.

Williams, T.A., and Graham, S.A., 2013, Controls on forearc basin architecture from seismic and sequence stratigraphy of the Upper Cretaceous Great Valley Group, central Sacramento Basin, California: International Geology Review, v. 55, p. 2030-2059, https://doi.org/10.1080/00206814 2013.817520

Williams, T.A., Graham, S.A., and Constenius, K.N., 1998, Recognition of Santonian submarine canyon, Great Valley Group, Sacramento Basin, California: Implications for petroleum exploration and sequence stratigraphy of deep-marine strata: American Association of Petroleum Geologists Bulletin, v. 82, p. 1575-1595.

Wright, J.E., and Wyld, S.J., 2007, Alternative tectonic model for Late Jurassic through Early Cretaceous evolution of the Great Valley Group, California, in Cloos, M., Carlson, W.D., Gilbert, M.C., Liou, J.G., and Sorensen, S.S. eds., Convergent Margin Terranes and Associated Regions: A Tribute to W.G. Ernst: Geological Society of America Special Paper 419, p. 81-95, https://doi.org/10.1130/2007.2419(04).

Zieglar, D.L., and Spotts, J.H., 1978, Reservoir and source-bed history of Great Valley, California: American Association of Petroleum Geologists Bulletin, v. 62, p. 813-826. 